\title{
Local Economic Development in the Context of the Institutional Efficiency of Local Governments
}

\author{
Renata Marks-Bielska, Magdalena Wojarska, Wieslawa Lizinska, Karolina Babuchowska
}

\author{
University of Warmia and Mazury in Olsztyn \\ Oczapowskiego st. 4, 10-719, Olsztyn, Poland \\ E-mail.renatam@uwm.edu.pl; magdaw@uwm.edu.pl; wieslawa.lizinska@uwm.edu.pl; karolina.babuchowska@uwm.edu.pl
}

cross $^{\text {ref }}$ http://dx.doi.org/10.5755/j01.ee.31.3.22261

Institutional efficiency of local governments can be defined as permanent readiness to shape economic and social partnerships with both entrepreneurs and local residents, as well as a capacity to provide prompt and competent responses to expectations of business people willing to start or already conducting business in a given municipality. Evaluation of efficiency pertains to the ability of a local government to express its goals, to agree about these goals with the local community and to be efficient in making decisions. The results of international studies demonstrate that in the long run the quality of institutions determines the wealth of individual countries. Socio-economic development depends not only on the economic base and financial support opportunities but also on factors that involve institutions. Bearing above in mind the main purpose of this article was to diagnose the type, direction and extent of interactions between the level of development and institutional efficiency of local governments in Poland. To reach it, the research team used both secondary data (from public statistics) and original data (acquired through a survey study comprising 1,120 representatives of local authorities). The level of efficiency of local governments was assessed with a synthetic measure of efficiency (EFF), whereas development was measured with a synthetic development index (DEV). The results show that the local governments were in a rather unfavorable situation in terms of both efficiency and development. In both cases, the average value of the synthetic measure applied reached a value equal to $30 \%$ of the highest possible score. Research proved that there was a correlation relationship between EFF and DEV measures $(r=0.365)$. In addition, it turned out that the power of impact of development processes resulting in some improvement of efficiency is more intensive than the effect of efficient functioning of municipalities on the development processes that occur within them.

Keywords: Institutional Efficiency of Local Governments; Level of Local Development; Municipalities in Poland, Synthetic Measure; Analysis of Regression.

\section{Introduction}

The question of institutions affecting different economic processes is increasingly important in both theoretical and empirical research (e.g. Chong \& Calderon, 2000; Gimzauskiene \& Kloviene, 2011; Law \& Azman-Saini, 2012; Breen \& Gillanders, 2012; Grigoli \& Mills 2014; Andreula \& Chong 2016). Most economists have agreed that a fundamental statement underlying new institutional economics (NIE) is the claim that institutions determine the long-term rate of economic growth. In many publications, representatives of the World Bank, International Monetary Fund and OECD highlight the role of institutions in creating proper conditions for economic development (e.g., the World Bank's report Building Institutions for Markets). Over the recent years, the European Union has reinforced the regulatory pillar of economic policy, for example through its Better Regulations initiative or the so-called internationalisation of the Lisbon Strategy and by obligating the member states to develop complex programmes of amendments to legal regulations. According to NIE, good institutions, that is, ones that contribute to improved adaptation and allocation efficiency, are adjusted to fit the local social and cultural context (Wilkin et al., 2013).

A review of the research into NIE supports the claim that there has been a change in the perspective of studies on institution. In the 1990s, the focus was on determining the contribution of institutions to the shaping of incomes around the world, as well as their influence on economic growth (Acemoglu, 2008; Acemoglu et al., 2001; Hall \& Jones, 1999; Kaufmann \& Kraay, 2002; Kaufmann et al., 1999; Kaufmann et al., 2003; Knack \& Keefer 1995, 1997; Landes, 2000; Mauro, 1995; Rodrik, 1999; Rodrik, 2003, Rodrik et al., 2004; Woolcock \& Narayan, 2000). The results of international studies demonstrate that in the long run the quality of institutions determines the wealth of individual countries (Acemoglu et al., 2005; Williams, 1997). Socioeconomic development depends not only on the economic base and financial support opportunities but also on factors that involve institutions (Gibbs et al., 2001; MacLeod \& Goodwin, 1999). The purpose of local development, in compliance with the guidelines of the World Bank, the UN and OECD countries, is to build and activate the potential of a given territorial unit, e.g. a municipality, to attain better economic future, and to improve the quality of life of local residents (Kisman \& Tasar 2014). It is particularly important to establish connections between the intention of local authorities to develop the administrative unit they govern with the creation of suitable conditions for business entities (Walzer, 2009). Local authorities cannot have direct influence on all conditions which encourage the inflow of investments (e.g. local selling market, the geographical location). It is 
important to recognize the needs and provide them of current and potential investors in accordance with the capabilities of local governments (e.g. local tax incentives, assistance in making contact between investors and business environment institutions, cooperation with R\&D institutions, conditions as the state of technical infrastructure, technical state of office and production space available for possible investment projects, quality and efficiency of services provided by municipal clerks, right attitude of local authorities and community towards entrepreneurs, accessibility of areas dedicated to investment projects, building resources of professional workforce by ensuring access to education, etc.).

Many researchers (including Baumol, 1990; Minniti \& Levesque, 2008; Shane, 2009; Williams \& Shahid, 2016; Williams et al., 2017) have proven the predominant impact of institutional support on business activity. The attitudes, competences and actions of local authorities undertaken to attract investors are an important element conditioning local development.

Presently, more attention is paid to the quality of institutions, especially on the macro-economic level (Álvarez-Diaz \& Miguez, 2008). Few papers address the efficiency of institutions (Chousa et al., 2005; Putnam, 1995), particularly on a local level.

For a local government to facilitate development, it must possess a certain level of efficiency in its executive actions, which inter alia relies on adequate administrative skills. Local governments must be highly active to meet this challenge as they function in the conditions of constant shortages of funds and other resources, including material assets and human resources. Hence, there is a need to search for solutions that will enable municipalities in Poland to act more effectively and efficiently.

This thread appears, among others in the research of $\mathrm{P}$. Swianiewicz, W. Dziemianowicz and M. Mackiewicz (2000), which focused on the analysis of institutional efficiency in Polish communes in seven dimensions, i.e. the quality of service in the municipal office, integrity in administration, ability to undertake innovative activities, quality of planning and financial management, quality of legislation passed by municipal council, political stability, economic development policy. The authors assumed that the institutional efficiency of a local government consists of the ability to respond to the needs of the local community, agree on goals, efficient decision-making and implementation of agreed goals.

These studies inspired us to find the existing gap in previous research and try to fill it by undertaking a scientific problem pertain to searching for relationships between institutional efficiency and economic growth on a local level. It is additionally supported by the theory of endogenous regional development, which emphasises the role of public authorities (especially local ones) in shaping conditions for social and economic development. The main aim of the analysis was to diagnose the type, direction and extent of interactions between the level of development and institutional efficiency of local governments in Poland. The object of this study concentrated on reciprocal relationships between these two categories. To achieve the research aim several methods were used including linear ordering of multi- feature objects (using a synthetic measure calculated as a mean value of normalised values of partial indices) as well as correlation and a regression analysis (one- and two-equation variants). The research was undertaken as part of the project "Institutional Efficiency vs. Local Economic Development Determinants and Interactions". It was financed from the funds of the National Centre of Science, according to decision number DEC-2013/09/B/HS4/03039.

\section{Institutional Efficiency and Development of Local Governments in Light of the Subject Literature}

In accordance with the guidelines of NIE, a local government is a formal institution that belongs to organisations and that functions in an economy parallel to two other groups of institutions (norms and markets) (North, 1984). For any institution to function properly, it is essential that state organisations act efficiently.

Efficiency is a term frequently used with respect to public services and - more broadly - to public organisations, including administration and the state as a whole. Robbins and DeCenzo (2002) associate the term efficiency with minimising the costs of resources. In recent years, the complexity of functions, scale, objective and responsibility are components of the contemporary circumstances in which local governments operate. A local government is a response to such conditions as it is only by being able to build local potential and implement local solutions that we are capable of meeting the challenges created by the above complexities. Local governance systems can be divided into two categories: local governments that seek to perform all their functions in a balanced manner and those that strive towards greater efficiency in some selected functions (Stoker, 2011).

An important role played by municipal authorities is to stimulate and energise development processes of the local economy. Activities undertaken in the field of local economic policy have the aims of maintaining the presence of existing business enterprises, support their further development, acquiring new enterprises, etc.

As underlined by Torres et al. (2011), local governments in all EU member states participate in the development of systems and instruments for measuring the effects of their operations. These are thought to be a significant element serving to improve the effectiveness and efficiency of the above institutions, while performance management is on the agenda of many local governments, where it is seen as public expression of the attention they give to the appropriate allocation of taxpayers' money.

Standards applying to the functioning and assessment of public administration units, including local governments, evolve constantly and are increasingly based on the criterion of efficiency. The importance of efficiency is highlighted in the preamble to the Constitution of the Republic of Poland: 'Desiring to guarantee the rights of the citizens for all time, and to ensure diligence and efficiency in the work of public bodies'. However, this notion bears numerous meanings, and broadly efficiency ${ }^{1}$ is synonymous to each of the values of practical action (accuracy, effectiveness, simplicity). 
Institutional efficiency, referring to the functioning of institutions, including local governments, has been defined for the purpose of our own research (Marks-Bielska et al., 2017) as permanent readiness to shape economic and social partnerships with both entrepreneurs and local residents, as well as a capacity to provide prompt and competent responses to expectations of business people willing to start or already conducting business in a given municipality. Evaluation of efficiency pertains to the ability of a local government to express its goals, to agree about these goals with the local community and to be efficient in making decisions.

The most essential area in which public sector organisations are active is the provision of public services. Pursuant to the requirement of public accessibility, these tasks should not be governed by market regulations sensu stricto. After all, their overriding aim is not financial gain but rather maximisation of social benefits. This implicates the need to finance such type of services from public funds. At the same time, budget constraints currently felt by the entire public administration sector mean that the highest quality services must be provided in the most efficient and profitable manner (Communication from the Commission, 2011). In this context, the role of efficient local government institutions gains importance because efficient authorities can take advantage of emerging opportunities to further the development of their local communities (Wojarska et al., 2017).

As emphasised by Milaszewicz (2017), there is widespread agreement in the literature that high quality of governance (quality of government ${ }^{2}$ ) is a prerequisite for long-term and sustainable growth in living standards (Dellepiane-Avellaneda, 2010). In the Polish references addressing the subject, researchers have reported investigations on changes in the perception of public administration. Considering the experiences of local government administration, it is worth noting that actions have long been taken to improve this perception by increasing local government efficiency and effectiveness (Lizinska et al., 2017; Marks-Bielska \& Kurowska, 2017).

Two main views are expressed in the literature on interactions between economic development and institutional efficiency. On the one hand, the importance of institutional efficiency as a key stimulus for development (and this view is dominant) is indicated (Evans \& Harding 1997). The proponents of the other standpoint do not negate the dependence implicating that development determines efficiency. It can also be observed that efficient functioning of a given local government can be stimulated, for example, by the activity of local governments in adjacent municipalities (Geys, 2006). Afonso and Fernandes (2008) claim that institutional efficiency can be improved without having to increase expenditure. Other factors that affect institutional efficiency are those that refer to internal conditions, within a local government, treated as an

\footnotetext{
${ }^{2}$ Quality of Government ( $\left.Q o G\right)$ and related concepts (Good Governance) or the efficiency of a state (State Capacity) refer to the desired effect of performing public authority (Agnafors, 2013) and largely on the national level. Each of these concepts, however, takes into account different aspects of institutions and authority held and proposes assessing different dimensions of authorities. The multi-dimensional character of the quality of government as a concept means that the literature contains various
}

organisation in which the development of its administrative sphere is important, which agrees with Fayol's principles ${ }^{3}$ that formed the Administrative Management school of thought.

Social and economic development on a local level requires an appropriate level of efficiency of executive activities, based on adequate administrative skills. The results of surveys and analyses among local governments in Poland (Lizinska et al., 2016) suggest that institutional efficiency, for instance in the field of administrative decisions issued by local authorities, is still largely problematic. Meanwhile, it is difficult to observe positive changes in the quality of decisions issued by public administration in individual cases.

The authority held by a municipality in terms of spatial management makes it a legal subject in both land use and the form of land use planning (planning authority). In this respect, emphasis can be laid on the exclusivity of the municipality, as no other unit of local government or government administration has such competence (MarksBielska, 2011). Taking into account the above, local authorities should make constant efforts towards rational use and development of space.

The existence and development of local governments require strong financial foundations. The ability to finance tasks (financial potential), in conjunction with proper financial management, conditions the proper functioning and development of local government units (Wallis \& Dollery, 2010).

The research completed under the project 'System support of management processes in local government units' (Frączek, 2014), funded by the Ministry of Administration and Digitalisation, demonstrated that the growing complexity of social and economic problems is forcing local governments in Poland to take action in advance, to be ready to address problems at the time they occur and not just to think about possible actions; local authorities must therefore change their philosophy to proactive (instead of reactive). It is important that local governments cooperate with local/regional stakeholders. Additionally, agreement must be reached on a common space of action between different levels of local government in Poland, which unfortunately is often problematic. It is also crucial to build relationships between the national government and local governments. Too often, despite the fundamental subsidiarity principle inscribed in the Polish state system, the central government does not allow local governments to implement responsible and autonomous policies.

\section{Research Methods}

To achieve the research aim, which was to identify dependences between institutional efficiency and the level of development of Polish municipalities, the research hypothesis predicting that there are some interactions

definitions of QoG as well as suggesting different approaches to making assessments and ranking lists of countries, e.g., Tomini (2011), Agnafors (2013), Hallerod et al. (2014), Milaszewicz (2017).

${ }^{3}$ The creator of the administrative theory of management in the so-called narrow sense, in which he identified groups of actions: predicting, organising, giving orders, coordinating and supervising. 
between the two categories was verified. The verification was based on secondary data (originating from the resources of the Local Data Bank ${ }^{4}$ ) and original data (obtained through a survey). The research procedure was conducted according to an algorithm consisting of a total of four stages.

Stage I comprised theoretical studies of the subject literature and a thorough analysis of the research results from other scientific centers. The basic premise of this part of the research was to define sets of indicators that would fully describe the phenomena studied, i.e., efficiency and development. Final set of indicators used to evaluate the efficiency of local governments and the ones on the basis which the level of development was assessed can be found in (Wojarska, et al., 2018). In general, mixed data (secondary and primary) were used to assess efficiency, which was grouped according to the basic areas of activity of the local government. The economic and spatial sphere was described using variables that take into account the activities of local authorities regarding instruments supporting entrepreneurship, cooperation between local government and entrepreneurs and other institutions, activity in the scope of improving communal infrastructure and space management, as well as non-profit organizations operating in the commune. In the financial area the following issues were included: value of the municipality's public debt, value of the municipal budget result, contribution of funds acquired from the EU budget in the municipal budget total revenue and actions of local governments whose aim is to rationalise the management of finances (including the management of the debt) and contribution of the local community to the planning of investments financed from the municipal budget. In the administrative area, issues related to the activities of the commune office, functioning of local authorities and expenditure from communes budgets were assessed. Human resources management in the commune office was characterized by the activities in the field of improving the qualifications and skills of office employees, issues about conducting effective employment policy and improving the interpersonal communication system. Within the sphere of providing social, cultural and educational services, the subject of interest were issues related to the scope and quality of obligatory services provided by the commune, the scope of additional services, expenditure on these services and places in nurseries and kindergartens. On the other hand, indicators based on secondary data were used to assess the level of development of the surveyed communes, which represented the basic aspects of this phenomenon, i.e.: financial economy of the commune, infrastructure development, entrepreneurship, the situation on the labor market and socio-demographic issues.

Stage II consisted of the aggregation of data, which were then arranged in sets of data within purpose-designed databases. In order to gather all the necessary information, a survey questionnaire was established. It consisted of 50

\footnotetext{
${ }^{4}$ The Local Data Bank (LDB) (accessible at: https://bdl.stat.gov.pl/BDL/start) is the largest, ordered set of data in Poland providing information about the social, economic, demographic and environmental situation in the country, and describing administration units at all levels of the territorial division of Poland. It offers over 40,000 statistical measures grouped under subject headings according to the research programme in the public statistics area.
}

questions (mostly semi-open-ended ones) and its purpose was to learn about the procedures, organisation of processes, applied tools and their advancement, to assess the effect of implemented activities in the following areas: economic and spatial, financial, administrative, human resources management in municipal offices, provision of social, cultural and educational services. Responses to particular questions were assigned point scores. Sums of points obtained from individual replies and average values of selected statistical indicators (from the LDB) pertaining to municipalities served to calculate values of the efficiency index for each local government studied.

Original data were collected during the survey study, which was addressed to representatives of local authorities and took place at the turn of 2015/2016. Fully and correctly completed questionnaires were received from 1,220 municipalities (150 from urban municipalities, 770 from rural and 300 from urban-rural ${ }^{5}$ ), which yielded a response rate of $49.2 \%$ (an error of response in the sample obtained was 0.02). To verify whether the distribution of municipalities according to types obtained in the sample differed from that for the entire population, a chi-square test was performed. In each case, the result was not significant statistically $(\mathrm{p}>0.1)$, indicating the lack of significant differences between the observed distribution (present in the sample) and the expected one (present in the population).

Stage III was when aggregate measures were established, which then served to evaluate the level of development (the DEV index) and institutional efficiency (the EFF index and partial indices for particular areas of efficiency $\mathrm{EFF}_{1}-\mathrm{EFF}_{5}$ ).

The measures DEV and EFF1-EFF5 were calculated using a mean value of normalised values of partial indices from table $2(\mathrm{DEV})$ and table $1\left(\mathrm{EFF}_{1}-\mathrm{EFF}_{5}\right)$.

In turn, the institutional efficiency index EFF was determined as a sum of partial indices EFF1-EFF5, including their weights, which were agreed on in discussions with experts, including representatives of municipal councils and offices, business environment institutions and business people:

$$
\begin{gathered}
\mathrm{EFF}=0.25 \mathrm{EFF}_{1}+0.25 \mathrm{EFF}_{2}+0.15 \mathrm{EFF}_{3}+0.20 \mathrm{EFF}_{4} \\
+0.15 \mathrm{EFF}_{5} \in\langle 0 ; 1\rangle
\end{gathered}
$$

where:

EFF - synthetic indicator of institutional efficiency of a local government,

$\mathrm{EFF}_{1}$ - synthetic indicator of institutional efficiency in the economic and social sphere,

$\mathrm{EFF}_{2}-$ synthetic indicator of institutional efficiency in finances,

$\mathrm{EFF}_{3}$ - synthetic indicator of institutional efficiency in administration,

$\mathrm{EFF}_{4}$ - synthetic indicator of institutional efficiency in human resources management in the municipal office,

$\mathrm{EFF}_{5}$ - synthetic indicator of institutional efficiency in the sphere of social, cultural and educational services.

${ }^{5}$ There are three types of municipalities in Poland: urban, rural, and urbanrural. More information about this classification is in the Regulation of the Council of Ministers of 15 December 1998 on detailed guidelines of keeping, using and making available the state official register of local government units in Poland. 
Because of the huge amount of data that appeared during an analysis of the information provided by 1,220 municipalities, the research team decided to divide the research sample into three distinct sub-groups, characterised by different degrees of efficiency or development. Group I comprised municipalities with the highest values of synthetic measures, i.e., those for which the EFF or DEV index was within the range $(\overline{\mathrm{x}}+\mathrm{SD}, \max \rangle$ (where $\overline{\mathrm{x}}-$ mean, $\mathrm{SD}$ - standard deviation, $\max$ - the highest value). Group II was composed of municipalities that satisfied the condition: $\mathrm{EFF}$ or $\mathrm{DEV} \in\langle\overline{\mathrm{x}}-\mathrm{SD}, \overline{\mathrm{x}}+\mathrm{SD}\rangle$ - these territorial units were treated as municipalities charactersed by a moderate level of efficiency or development. Group III included municipalities with the lowest values of the measure, i.e., the synthetic measure EFF or DEV within the range $\langle\min , \bar{x}-S D$ ) (where min - the lowest value).

Stage IV included the verification of the hypothesis predicting interactions between the level of development and the institutional efficiency of local governments. For this purpose, the Pearson's correlation coefficient and regression analysis were used. The former allowed us to identify the direction of dependence and its strength, while the latter served to make the result more precise by developing three econometric models, of which two were one-equation models and one contained two mutually dependent equations. The one-equation models were built for all municipalities together and for each type of municipality separately. Aggregate equations for the entire sample were enriched with dichotomous zero-one variables, which allowed us to examine the impact of the type of municipality. In this case, parameters of econometric models in the following form were submitted to estimations:

$$
y_{i}=\beta_{0}+\beta_{1} x_{i 1}+\beta_{2} x_{i 2}+\xi_{i} \quad(i=1, \ldots, 1.220)
$$

where:

$\mathrm{y}_{\mathrm{i}}$ - dependent variable in the regression equation (a development or efficiency indicator),

$\mathrm{x}_{\mathrm{i} 1}$ - explanatory variable in the form of a development or efficiency indicator,

$\mathrm{x}_{\mathrm{i} 2}$ - dichotomous variable, assuming the value 1 in the case of a given type of municipality: urban, rural or urbanrural, and the value 0 in the other cases,

$\beta_{0}, \beta_{1}, \beta_{2}-$ structural parameters of the model,

$\xi_{\mathrm{i}}$ - random element of the equation.

The identification of correlations between indicators describing the development and efficiency of municipalities was also based on estimations of two-equation models. To this aim, a model with reciprocally dependent equations was proposed:

$$
\left\{\begin{array}{l}
y_{i 1}=\beta_{0}+\beta_{1} y_{i 2}+\beta_{2} x_{i 1}+\xi_{i 1} \\
y_{i 2}=\alpha_{0}+\alpha_{1} y_{i 1}+\alpha_{2} x_{i 2}+\xi_{i 2}
\end{array}\right.
$$$$
\text { where: }
$$

$\mathrm{y}_{\mathrm{i} 1}, \mathrm{y}_{\mathrm{i} 2}-$ jointly dependent variables (development index and efficiency index),

$\mathrm{x}_{\mathrm{i} 1}, \mathrm{x}_{\mathrm{i} 2}$ - predetermined variables, i.e., share of own revenues in total revenue of the municipal budget and HR efficiency indicator of municipalities, model,

$\beta_{0}, \beta_{1}, \beta_{2}, \alpha_{0}, \alpha_{1}, \alpha_{2}$ - structural parameters of the

\footnotetext{
${ }^{6}$ The equations were estimated with the Least Squares Method (2LSM) using an econometric software package GRETL by Allin Cottrell, Wake Forest University, North Carolina, USA.
}

$\xi_{\mathrm{i} 1}, \xi_{\mathrm{i} 2}-$ random elements of the first and second equations in the model.

The ability to estimate models with dependent equations is synonymous to the identifiability of each equation of this model. This is why feedbacks between jointly dependent variables, i.e., development and efficiency, were supplemented with the influence exerted on them by so-called predetermined factors. These factors were composed of the variables most strongly correlated with the development index and the efficiency index, i.e., the share of own revenues in total revenue of municipal budgets and the human resources efficiency indicator. Equations in the model were identifiable unambiguously, which enabled us to estimate them with the indirect or double Least Squares Method $^{6}$

\section{Institutional Efficiency versus the Level of Development of Local Governments Exemplified by Municipalities in Poland}

The average value of the aggregate EFF index (0.30) justifies the claim that local governments in Poland achieve a relatively low level of efficiency. The highest level of efficiency $(\mathrm{EFF}=0.63)$ was noted in the rural municipality of Kleszczow (in Lodzkie voivodship), while the lowest $(\mathrm{EFF}=0.15)$ appeared in the rural municipality Miasteczko Krajenskie (in Wielkopolskie voivodship). The highestranking municipality owed its position to the high values of partial indicators $\left(\mathrm{EFF}_{1}-\mathrm{EFF}_{5}\right)$, which were much above the average values and even reached the maximum values in two spheres: administration and social, cultural and educational services $\left(\mathrm{EFF}_{3}=0.79 ; \mathrm{EFF}_{5}=0.63\right)$. In turn, the municipality located at the bottom of the list had all the indicators of the synthetic efficiency measure oscillating around the minimum value and reached it only in the sphere of $\mathrm{HR}$ management in the municipal office $\left(\mathrm{EFF}_{4}=0.00\right)$.

The most efficient local governments were found in towns, where the highest average value of the EFF index was achieved (0.36) (tab. 1). Against the backdrop of the other two types of municipalities, urban ones stood out by having a large percentage of local government units classified in the group with the highest level of institutional efficiency (group I) $(43.33 \%)$ while lacking any representatives in the group of municipalities with the lowest values of the aggregate measure (group III). Furthermore, they had the smallest range (0.26) and variability $(0.17)$ of the EFF indicator, as well as the lowest skewness $(0.23)$ and kurtosis $(-0.75)$. The high skewness resulted from a small surplus of municipalities whose efficiency estimated with the EFF measure was above the average $(50.67 \%)$, and the negative kurtosis value was attributed to the high dispersion of results around the central value, which was also confirmed by the histogram and box plot prepared for this group.

With respect to the aggregate measure of efficiency, the second position was occupied by urban-rural municipalities $(\mathrm{EFF}=0.31)$, while rural ones came last $(\mathrm{EFF}=0.29)$. Although the structure of both types of municipalities was dominated by the units scoring moderate values of the EFF 
measure (72\% of such municipalities among urban-rural ones and $68.05 \%$ among rural ones), the worse position of rural municipalities was caused by a nearly twice as high (compared to urban-rural local governments) percentage of units with a low level of efficiency (i.e., ones classified to group III). The situation was similar in nearly all the other analysed areas, such as the economic and spatial sphere; administration; HR management in municipal offices; and provision of social, cultural and educational services. The only sphere where rural municipalities excelled in efficiency (and won the first position) was the domain of finances. The average value of the $\mathrm{EFF}_{2}$ indicator calculated for this type of municipality was 0.48 , compared to 0.47 for urban-rural local government units and 0.46 for urban ones. This was also the only sphere of activity in which rural municipalities had the smallest percentage (among all types of local governments) of units within group III, which comprised local governments with the lowest values of the synthetic efficiency measure.

Table 1

Average EFF Index by Type and Group of Municipalities

\begin{tabular}{|c|c|c|c|c|c|c|}
\hline \multirow[t]{2}{*}{ Туре } & \multicolumn{2}{|c|}{$\begin{array}{c}\text { GROUP I } \\
\text { (0.364; 0.625> } \\
\text { 'high' }\end{array}$} & \multicolumn{2}{|c|}{$\begin{array}{c}\text { GROUP II } \\
\langle 0.237 ; 0.364\rangle \\
\text { 'moderate' }\end{array}$} & \multicolumn{2}{|c|}{$\begin{array}{c}\text { GROUP III } \\
\langle 0.154 ; 0.237) \\
\text { 'low' }\end{array}$} \\
\hline & $\%$ of $\mathbf{N}$ & $\overline{\mathrm{EFF}}$ & $\%$ of $\mathbf{N}$ & $\overline{\mathbf{E F F}}$ & $\%$ of $\mathrm{N}$ & $\overline{\mathbf{E F F}}$ \\
\hline $\begin{array}{l}\text { urban } \\
(\mathrm{N}=150)\end{array}$ & 43.33 & 0.415 & 56.67 & 0.311 & 0.00 & - \\
\hline $\begin{array}{l}\text { rural } \\
(\mathrm{N}=770)\end{array}$ & 10.13 & 0.407 & 68.05 & 0.299 & 21.82 & 0.218 \\
\hline $\begin{array}{l}\text { urban-rural } \\
(\mathrm{N}=300)\end{array}$ & 16.00 & 0.398 & 72.00 & 0.294 & 12.00 & 0.217 \\
\hline
\end{tabular}

As unsatisfactory as the assessment of institutional efficiency was an overall evaluation of the socio-economic development of the analysed municipalities. Analogously, this was due to the relatively low value of the synthetic measure of development DEV, which equalled just 0.30 (at a standard deviation of 0.05 and range of 0.47 ).

The highest value of the development index (DEV $=$ 0.64) was obtained by the rural municipality Kleszczow (Lodzkie voivodship), which owed its high position mostly to high tax revenues from several large companies located within its boundaries, i.e., a brown coal mine and the Belchatow power plant, as well as several business entities sited in the Kleszczow industrial park. Owing to these enterprises, the municipality achieved the highest own income per capita, which was 9,465.56 $\mathrm{EUR}^{7}$, while the average value of this indicator for the entire sample was 266.35 EUR, and the lowest was 83.61 EUR. Consequently, the subsequently calculated indicators also attained high values, e.g., share of own revenues in the municipality's total budget at $96.56 \%$ (with the average for 1,220 municipalities equal to $38.61 \%$ ) and expenditure on development projects from the municipal budget per capita 4,323.25 EUR (while the group's average was 141.63 EUR and the minimum result was 27.96 EUR). Moreover, the presence of large companies had a positive impact on the labour market, as evidenced by a relatively low percentage of registered unemployed persons in the total working-age population, which equalled $6.4 \%$ in the analysed time period.

The village of Dynow (Podkarpackie voivodship), with the DEV value of only 0.17 , fell to the last place on the list. In contrast to Kleszczow, which is close to main transportation routes, Dynow lies in the hilly region of south-eastern Poland, far from express roads or motorways. The low value of DEV in this case was due to the low values of the partial variables used for its determination - all the stimulants were below the average, while the destimulants were well above it.

This time also, the best-developed were towns (tab. 2). The DEV measure calculated for these municipalities exceeded the country's average by 0.07 , and the percentage of municipalities with the highest values of the synthetic measure was as high as $76.0 \%$. This group was also distinguished by the lowest variability $(0.09)$, range $(0.02)$ and standard deviation (0.03). Next were urban-rural municipalities $(\mathrm{DEV}=0.31)$, while last place - regarding the level of development - was occupied by rural municipalities $(\mathrm{DEV}=0.28)$. Despite the fact that nearly $3 / 4$ of municipalities in both types were those scoring moderate values of DEV (77.0\% in urban-rural municipalities and $71.56 \%$ in rural ones), second place was won by the urbanrural municipalities owing to their much higher percentage of local government units characterised by the highest development (i.e., classified as development group I). The share of class I units in the structure of urban-rural municipalities was $18.33 \%$, whereas the analogous proportion among rural municipalities was just $6.23 \%$. The reverse situation was observed when analysing the share of least developed municipalities (group III), which was much higher among rural local municipalities $(22.21 \%)$ than among urban-rural ones $(6.23 \%)$.

Table 2

Average DEV Index by Type and Group of Municipalities

\begin{tabular}{|c|c|c|c|c|c|c|}
\hline \multirow[t]{2}{*}{ type } & \multicolumn{2}{|c|}{$\begin{array}{c}\text { GROUP I } \\
(0.348 ; 0.636\rangle \\
\text { 'high' }\end{array}$} & \multicolumn{2}{|c|}{$\begin{array}{c}\text { GROUP II } \\
\langle 0.242 ; 0.348\rangle \\
\text { 'moderate' }\end{array}$} & \multicolumn{2}{|c|}{$\begin{array}{c}\text { GROUP III } \\
\langle 0.169 ; 0.242) \\
\text { 'low' }\end{array}$} \\
\hline & $\%$ of $\mathrm{N}$ & $\overline{\mathbf{D E V}}$ & $\%$ of $\mathbf{N}$ & $\overline{\mathbf{D E V}}$ & $\%$ of $\mathrm{N}$ & $\overline{\text { DEV }}$ \\
\hline $\begin{array}{l}\text { urban } \\
(\mathrm{N}=150)\end{array}$ & 76.00 & 0.379 & 24.00 & 0.325 & 0.00 & - \\
\hline $\begin{array}{l}\text { rural } \\
(\mathrm{N}=770)\end{array}$ & 6.23 & 0.385 & 71.56 & 0.283 & 22.21 & 0.222 \\
\hline $\begin{array}{l}\text { urban-rural } \\
(\mathrm{N}=300)\end{array}$ & 18.33 & 0.372 & 77.00 & 0.297 & 4.67 & 0.227 \\
\hline
\end{tabular}

As a concluding step in our considerations on the level of development of the surveyed municipalities, their geographical location was scrutinised. Less developed municipalities (DEV < 0.24) were evidently more numerous in the eastern part of Poland, while the most developed ones $(\mathrm{DEV}>0.35)$ were concentrated in western Poland.

The identification of dependences between the level of development and institutional efficiency of local governments was based on an analysis of the r-Pearson correlation coefficient and analysis of regression. The former procedure revealed that the dependence between distributions of the DEV and EFF measures was $r=0.365$ $(\mathrm{p}<0.001)$, which should be interpreted as an average

${ }^{7}$ In this paper the conversion ratio was $1 E U R=4.3281 P L N$. 
relationship. This means that an increase in the socioeconomic development of the analysed local governments was accompanied by a moderate increase in their efficiency, and vice versa. A fuller understanding of the diagnosed relationship was made possible by applying regression analysis, which identified the direction of these interactions.

The calculations demonstrate that the structural parameters for variables that indicate development or efficiency in all models were statistically significant at 0.05 , which confirms the presence of correlations between the analysed indicators. The results of estimates of regression equations for the sample of all municipalities in total (presented in tab. 3 and tab. 4) suggest that an increase in institutional efficiency by 0.1 caused an increase in the development index, regardless of which model was estimated, by an average of 0.019 (in the equation testing the effect of urban municipalities), 0.022 (in the equation applied to rural municipalities) and 0.031 (in the equation including urban-rural municipalities). In turn, an increase in the development index by 0.1 caused an average increase in the efficiency measure by 0.032 (in the model with urban municipalities), 0.037 (in the model with rural municipalities) and 0.044 (in the model with rural-urban municipalities). What followed was that a unit change in the development index caused a much greater effect in the form of an increasing efficiency index than was seen in the reverse situation. As for the models tested with respect to the development index, the effect of the type of municipality was noted. Parameters for the variables denoting an urban, rural or urban-rural municipality were statistically significant. They showed that the development index was higher by an average of 0.069 for urban municipalities and by an average of 0.015 for urban-rural ones than for the other types of local governments. The situation differed slightly with respect to rural municipalities, for which this indicator was 0.043 lower, on average, than the mean value determined for the other two types of local governments. The results presented in Table 2 suggest a weaker effect of the affiliation to a particular type of municipality on a change in the efficiency index value. A statistically significant effect appeared only in urban (0.037) and rural municipalities (0.017 ) but was absent in the case of urban-rural local governments $(p=0.922)$. However, it should be added that the above cross-sectional models explained the variability of the development index and efficiency index on a significant albeit low level. Regarding the models for the development index, the determination coefficient $\left(\mathrm{R}^{2}\right)$ was $29.5 \%, 27.7 \%$ and $14.7 \%$, respective to the type of municipality, and $16 \%$, $14.5 \%$ and $13.3 \%$ for the efficiency index.

Table 3

Results of the Estimation of the Model for the Development Index $\left(y_{i}\right)$ Including the Impact of the Type of Municipality ${ }^{8}$

\begin{tabular}{lccc}
\hline \multicolumn{1}{c}{ Variable } & $\begin{array}{c}\text { Estimate of } \\
\text { parameter }\end{array}$ & t statistics & $\mathbf{p}$ \\
\hline URBAN MUNICIPALITY & & & \\
constant & 0.2293 & 35.82 & 0.000 \\
efficiency $-\mathrm{x}_{\mathrm{i} 1}$ & 0.1899 & 8.90 & 0.000 \\
town $-\mathrm{x}_{\mathrm{i} 2}$ & 0.0689 & 16.74 & 0.000 \\
\hline $\mathrm{R}^{2}=0.295$ & $\mathrm{~S}_{\xi}=0.044 \quad \mathrm{~V}_{\xi}=0.154$ & $\mathrm{n}=1.220$ & \\
\hline
\end{tabular}

${ }^{8} R^{2}$-determination coefficient; $S_{\xi}$-standard deviations of residuals; $V_{\xi}-$ random variability coefficient; $n$-number of items in the sample.

\begin{tabular}{|c|c|c|c|}
\hline Variable & $\begin{array}{l}\text { Estimate of } \\
\text { parameter }\end{array}$ & t statistics & $\mathbf{p}$ \\
\hline \multicolumn{4}{|c|}{ RURAL MUNICIPALITY } \\
\hline constant & 0.2569 & 35.78 & 0.000 \\
\hline efficiency $-x_{i}$ & 0.2174 & 10.24 & 0.000 \\
\hline village $-\mathrm{x}_{\mathrm{i} 2}$ & -0.0434 & -15.56 & 0.000 \\
\hline $\mathrm{R}^{2}=0.277$ & $\mathrm{~S}_{\xi}=0.045 \quad \mathrm{~V}_{\xi}=0.153$ & $\mathrm{n}=1.220$ & \\
\hline \multicolumn{4}{|c|}{ URBAN-RURAL MUNICIPALITY } \\
\hline constant & 0.2008 & 29.37 & 0.000 \\
\hline efficiency $-\mathrm{x}_{\mathrm{i}}$ & 0.3008 & 13.53 & 0.000 \\
\hline town-village & 0.0147 & 4.50 & 0.000 \\
\hline \multicolumn{4}{|l|}{$\mathrm{x}_{\mathrm{i} 2}$} \\
\hline $\mathrm{R}^{2}=0.147$ & $\mathrm{~S}_{\xi}=0.049 \quad \mathrm{~V}_{\xi}=0.166$ & $\mathrm{n}=1.220$ & \\
\hline
\end{tabular}

Table 4

Results of the Estimation of the Model for the Efficiency Index $\left(y_{i}\right)$ Including the Effect of the type of Municipality

\begin{tabular}{|c|c|c|c|}
\hline Variable & $\begin{array}{c}\text { Estimate of } \\
\text { parameter }\end{array}$ & t statistics & $\mathbf{p}$ \\
\hline \multicolumn{4}{|c|}{ URBAN MUNICIPALITY } \\
\hline constant & 0.2013 & 19.26 & 0.000 \\
\hline development - & 0.3216 & 8.90 & 0.000 \\
\hline town $-\mathrm{x}_{\mathrm{i} 2}$ & 0.0367 & 6.28 & 0.000 \\
\hline $\mathrm{R}^{2}=0.160$ & $\mathrm{~S}_{\xi}=0.058 \quad \mathrm{~V}_{\xi}=0.193$ & $\mathrm{n}=1.220$ & \\
\hline \multicolumn{4}{|c|}{ RURAL MUNICIPALITY } \\
\hline constant & 0.2035 & 16.99 & 0.000 \\
\hline development - & 0.3650 & 10.24 & 0.000 \\
\hline village $-\mathrm{x}_{\mathrm{i} 2}$ & -0.0166 & -4.24 & 0.000 \\
\hline $\mathrm{R}^{2}=0.145$ & $\mathrm{~S}_{\xi}=0.058 \quad \mathrm{~V}_{\xi}=0.193$ & $\mathrm{n}=1.220$ & \\
\hline \multicolumn{4}{|c|}{ URBAN-RURAL MUNICIPALITY } \\
\hline constant & 0.1724 & 18.08 & 0.000 \\
\hline development - & 0.4346 & 13.53 & 0.000 \\
\hline town-village - & $-\mathrm{x}_{\mathrm{i} 2} \quad 0.0004$ & 0.10 & 0.922 \\
\hline $\mathrm{R}^{2}=0.133$ & $\mathrm{~S}_{\xi}=0.059 \quad \mathrm{~V}_{\xi}=0.196$ & $\mathrm{n}=1.220$ & \\
\hline
\end{tabular}

The estimates of linear regression equations for the type of municipality (presented in tab. 5 and tab. 6) confirm the dependences observed earlier. An increase in development induced by an increase in institutional efficiency appeared to be the highest in urban municipalities and the lowest in rural ones - the regression coefficients for the three types of municipalities were 0.193 (urban municipalities), 0.145 (rural ones) and 0.190 (urban-rural ones). In turn, a rise in the development index by a unit caused an increase in the efficiency index by an average of 0.684 in urban municipalities, 0.229 in rural municipalities and 0.385 in urban-rural municipalities.

Table 5

Results of the Estimation of the Model for the Development Index $\left(y_{i}\right)$ According to the Type of Municipality

\begin{tabular}{|c|c|c|c|}
\hline Variable & $\begin{array}{c}\text { Estimate of } \\
\text { parameter }\end{array}$ & t statistics & $\mathbf{p}$ \\
\hline \multicolumn{4}{|c|}{ URBAN MUNICIPALITY } \\
\hline constant & 0.2972 & 20.23 & 0.000 \\
\hline efficiency $-\mathrm{x}_{\mathrm{i}}$ & 0.1929 & 4.74 & 0.000 \\
\hline $\mathrm{R}^{2}=0.132$ & $\mathrm{~S}_{\xi}=0.031 \quad \mathrm{~V}_{\xi}=0.084$ & $\mathrm{n}=150$ & \\
\hline \multicolumn{4}{|c|}{ RURAL MUNICIPALITY } \\
\hline constant & 0.2343 & 28.25 & 0.000 \\
\hline efficiency $-\mathrm{x}_{\mathrm{i}}$ & 0.1454 & 5.15 & 0.000 \\
\hline $\mathrm{R}^{2}=0.033$ & $\mathrm{~S}_{\xi}=0.045 \quad \mathrm{~V}_{\xi}=0.163$ & $\mathrm{n}=770$ & \\
\hline \multicolumn{4}{|c|}{ URBAN-RURAL MUNICIPALITY } \\
\hline constant & 0.2496 & 20.37 & 0.000 \\
\hline efficiency $-\mathrm{x}_{\mathrm{i}}$ & i1 $\quad 0.1898$ & 4.84 & 0.000 \\
\hline $\mathrm{R}^{2}=0.073$ & $\mathrm{~S}_{\xi}=0.041 \quad \mathrm{~V}_{\xi}=0.133$ & $\mathrm{n}=300$ & \\
\hline
\end{tabular}

Source: the authors 
Results of the Estimation of the Model for the Efficiency Index $\left(y_{i}\right)$ According to the Type of Municipality

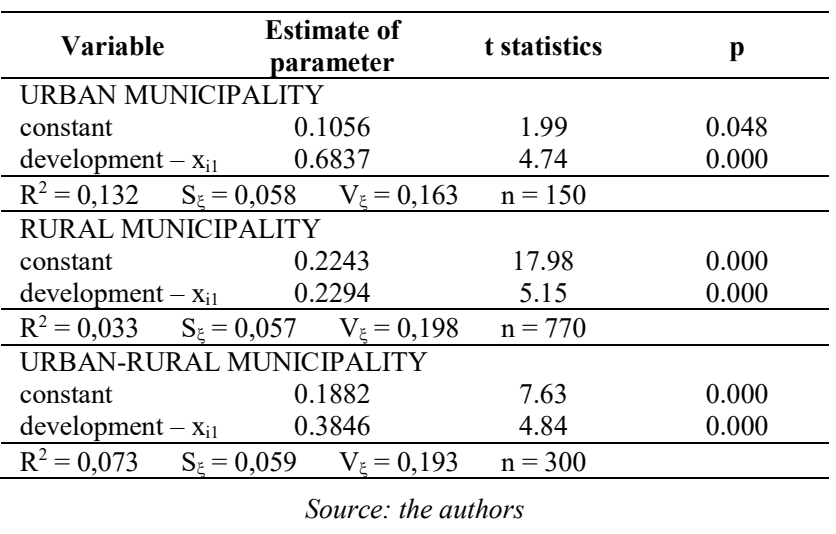

Another approach towards verification of the hypothesis that there are interactions between the development of municipalities and their efficiency consisted of an estimation of a two-equation model. The results (tab. 7) demonstrate the presence of significant feedback relations between the development index and the institutional efficiency index of municipalities. Parameters for the jointly dependent and predetermined variables were statistically significant at the level of at least 0.05 . Analogously to single equation models, the development index caused a much stronger effect in the form of an increase in the efficiency index than reversely. In this case, an increase in the efficiency index by 0.1 resulted in an increase in the development index by 0.005 , whereas a unit increase in the development index raised the efficiency index by 0.026 . The models reflected the shaping of the analysed indices on a relatively high level of over $70 \%$.

Table 7

Results of the Eestimation of 2LSM of Equation of the Model for the Development Index and the Efficiency Index

\begin{tabular}{|c|c|c|c|}
\hline Variable & $\begin{array}{l}\text { Estimate of } \\
\text { parameter }\end{array}$ & t statistics & $\mathrm{p}$ \\
\hline \multicolumn{4}{|c|}{ EQUATION OF DEVELOPMENT INDEX $\left(\mathrm{y}_{\mathrm{i} 1}\right)$} \\
\hline constant & 0.1667 & 35.34 & 0.000 \\
\hline efficiency $-\mathrm{y}_{\mathrm{i} 2}$ & 0.0529 & 3.12 & 0.001 \\
\hline $\begin{array}{l}\text { Share of own revenue } \\
-x_{i 1}\end{array}$ & 0.0029 & 48.09 & 0.000 \\
\hline $\mathrm{R}^{2}=0.709 \quad \mathrm{~S}_{\xi}=0.028$ & $\mathrm{~V}_{\xi}=0.095$ & $\mathrm{n}=1.220$ & \\
\hline \multicolumn{4}{|c|}{ EQUATION FOR EFFICIENCY INDEX ( $\left.\mathrm{y}_{\mathrm{i} 2}\right)$} \\
\hline constant & 0.1749 & 26.47 & 0.000 \\
\hline development $-\mathrm{y}_{\mathrm{i} 1}$ & 0.2582 & 11.29 & 0.000 \\
\hline $\begin{array}{l}\text { efficiency of human } \\
\text { resources }-\mathrm{x}_{\mathrm{i} 2}\end{array}$ & 0.2397 & 47.95 & 0.000 \\
\hline $\mathrm{R}^{2}=0.708 \quad \mathrm{~S}_{\xi}=0.034$ & $V_{\xi}=0.123$ & $\mathrm{n}=1.220$ & \\
\hline
\end{tabular}

The results of the correlation analysis and regression analysis substantiate the conclusion that the hypothesis assuming the presence of interactions between the level of local development and institutional efficiency of local governments was verified positively.

\section{Conclusion}

The main objective of this study was to diagnose the type, direction and strength of interactions between the level of development and institutional efficiency of local governments in Poland. It was achieved through the verification of the hypothesis that assumed the presence of interactions between institutional efficiency and local development. The main instruments were an analysis of correlations and analysis of regression (one- and twoequation models). Both procedures confirmed the existence of the presumed relationships. The Pearson's correlation coefficient was 0.365 , thus informing us that an increase in the socio-economic development of the analysed municipalities was accompanied by a moderate increase in their efficiency and vice versa. An answer to the question about the direction of the above interactions was supplied by the analysis of regression, which demonstrated the presence of significant feedback relationships between the examined categories, with the effect of development being stronger. This means that the power of impact of development processes resulting in some improvement of efficiency is more intensive than the effect of efficient functioning of municipalities on the development processes that occur within them. The most likely cause can be seen in exogenous phenomena, which are outside the reach of local governments but force them to take action, which ultimately translates into their improved efficiency. Thus, a local government that acts efficiently is one that, while aiming to better the socioeconomic situation, uses the endogenous potential to the highest possible degree, supporting its efforts with an optimal combination of tools. It builds partner relationships with various categories of stakeholders (entrepreneurs, potential investors, non-government organisations) and is able to respond promptly and competently to the needs they signal. It is skilful at defining its goals while engaging the local community in this process, and once the aims are defined, it makes decisions promptly and without undue delay to achieve the set goals. An efficient local government is also able to respond appropriately to exogenous factors - it can take full advantage of opportunities and minimise the impact of threats as much as possible. Therefore, local authorities should focus on strengths resulting from internal potential and also: intensify the use of pro-development tools, including incentives for investors in the form of lowering local tax rates, undertake joint ventures with the private sector, develop technical and social infrastructure, increase cooperation with business environment institutions and local and regional governments.

At the end some limitations of the study should be pointed out. Firstly, it is ambiguity of the terms 'institutional efficiency' and 'local development' as well as the lack of common approach to described them by one unified set of indicators.

Secondly, a narrow range of indicators offered by public statistics that accurately describe the category of institutional efficiency caused the need to collect original data from local governments. The drawback of this kind of information is that it always combines facts with some subjective opinion of the respondent.

Our research focused mainly on the diagnosis of the existing situation, i.e. searching the answer to the question about the level of efficiency and development as well as the relationships between these categories. The research material provided us the basis for designing the subsequent research. It should focus on finding the specific causes of the diagnosed low level of development and low efficiency and proposing tools for improving the situation. 


\section{References}

Acemoglu, D. (2008). Introduction to modern economic growth. Princeton: Princeton University Press.

Acemoglu, D., Johnson, S., \& Robinson, J. (2005). Institutions as the fundamental cause of long-run growth. In: P. Aghion \& S. N. Durlauf (Ed.), Handbook of economic growth (pp. 386-472). North Holland, Amsterdam: Elsevier. https://doi.org/10.1016/S1574-0684(05)01006-3

Acemoglu, D., Johnson, S., \& Robinson, J. A. (2001). The colonial origins of comparative development: an empirical investigation. American Economic Review, 91(5), 1369-1401. Available from internet: https://economics.mit.edu/ files/4123. https://doi.org/10.1257/aer.91.5.1369

Afonso, A., \& Fernandes, S. (2008). Assessing and explaining the relative efficiency of local government. The Journal of Socio-Economics, 37(5), 1946-1979. https://doi.org/10.1016/j.socec.2007.03.007

Agnafors, M. (2013). Quality of government: toward a more complex definition. American Political Science Review, 107(3), 433-445. https://doi.org/10.1017/S0003055413000191

Alvarez-Diaz, M., \& Miguez, G. C. (2008). The quality of institutions: a genetic programming approach. Economic Modelling, 25(1), 161-169. https://doi.org/10.1016/j.econmod.2007.05.001

Andreula, N., \& Chong, A. (2016). Do good institutions improve fiscal transparency? Economics of Governance, 17, 241263. https://doi.org/10.1007/s10101-015-0175-8

Baumol, W. J. (1990). Entrepreneurship: Productive, Unproductive, and Destructive. Journal of Political Economy, 98(5), Part 1 (Oct., 1990), 893-921. https://doi.org/10.1086/261712

Bober, J., Hausner, J., Izdebski, H., et al., (2013). Raport o stanie samorządnosci terytorialnej, narastające dysfunkcje, zasadnicze dylematy, konieczne dzialania. Krakow: UE Krakow. Available from internet: http://www.msap.uek. krakow.pl/doki/publ/raport_dysfunkcje.pdf.

Breen, M., \& Gillanders, R. (2012). Corruption, institutions and regulation. Economics of Governance, 13, $263-285$. https://doi.org/10.1007/s10101-012-0111-0

Chong, A., \& Calderon, C. (2000). Institutional quality and poverty measures in a cross-section of countries. Economics of Governance, 1, 123-135. https://doi.org/10.1007/s101010050002

Chousa, J. P., Khan, H. A., Melikyan, D., et al. (2005). Assessing institutional efficiency, growth and integration. Emerging Markets Review, 6(1), 69-84. https://doi.org/10.1016/j.ememar.2004.09.004

Communication from the Commission to the European Parliament, the Council, the European Economic and Social Committee and the Committee of the Regions. A Quality Framework for Services of General Interest in Europe (COM(2011) 900 final).

Dellepiane-Avellaneda, S. (2010). Review article: good governance, institutions and economic development: beyond the conventional wisdom. British Journal of Political Science, 40 (1), 195-224. Available from internet: https://www.researchgate.net/publication/232028001 Review Article Good Governance Institutions and Economic_Development_Beyond_the_Conventional_Wisdom. https://doi.org/10.1017/S0007123409990287

Evans, R., \& Harding, A. (1997). Regionalisation, regional institutions and economic development. Policy \& Politics, 25(1), 19-30. https://doi.org/10.1332/030557397782213765

Fraczek, M. (2014). Sprawne Panstwo. Czy Konieczne są Systemowe Zmiany Funkcjonowania Jednostek Samorzadu Terytorialnego? Krakow: Malopolska Szkola Administracji Publicznej. Available from internet: http://pri.msap.pl/ doki/publ/SWPZ_Sprawne_panstwo_2014.pdf

Geys, B. (2006). Looking across borders: a test of spatial policy interdependence using local government efficiency ratings. Journal of Urban Economics, 60(3), 443-462. https://doi.org/10.1016/j.jue.2006.04.002

Gibbs, D. C., Jonas, A. E. G., \& Reimer, S., et al. (2001). Governance, institutional capacity and partnerships in local economic development: theoretical issues and empirical evidence from the Humber Sub-region. Transactions of the Institute of British Geographers, 26(1), 103-119. Available from internet: https://www.jstor.org/stable/623147? seq=1\#page_scan_tab_contents. https://doi.org/10.1111/1475-5661.00008

Gimzauskiene, E., \& Kloviene, L. (2011). Performance Measurement System: Towards an Institutional Theory. Inzinerine Ekonomika-Engineering Economics, 22(4), 338-344. https://doi.org/10.5755/j01.ee.22.4.709

Grigoli, F., \& Mills, Z. (2014). Institutions and public investment: an empirical analysis. Economics of Governance, 15, 131-153. https://doi.org/10.1007/s10101-013-0137-y. https://doi.org/10.1007/s10101-013-0137-y 
Renata Marks-Bielska, Magdalena Wojarska, Wieslawa Lizinska, Karolina Babuchowska. Local Economic Development...

Hall, R., \& Jones, C. (1999). Why do some countries produce so much more output per worker than others? The Quarterly Journal of Economics, 114(1), 83-116. https://doi.org/10.1162/003355399555954

Hallerod, B., Ekbrand, H., \& Gordon, D. (2014). Good governance - what we think it is and what we really measure. In: The quality of government and the performance of democracies. Early draft presented at the quality of government and the performance of democracies seminar, Gothenburg, May 20-22, 2014. Available from internet: http://qog.pol.gu.se/digitalAssets/1530/ 1530012_haller--d--ekbrand--gordon.pdf.

Joe, W., \& Brian, D. (2010). Alternatywne mechanizmy rządzenia na szczeblu samorządow lokalnych z perspektywy nowej ekonomii instytucjonalnej. Zarządzanie Publiczne, 1(11), 71-88. Available from internet: http://bazhum.muzhp.pl/media//files/Zarzadzanie_Publiczne/Zarzadzanie_Publiczne-r2010-t-n11_(1)/Zarzadzanie Publiczne-r2010-t-n11_(1)-s71-88/Zarzadzanie_Publiczne-r2010-t-n11_(1)-s71-88.pdf.

Kaufmann, D., \& Kraay, A. (2002). Growth without governance. Washington: The World Bank. Available from internet: http://siteresources.worldbank.org/DEC/Resources/GGLAC11.pdf.

Kaufmann, D., Kraay, A., \& Mastruzzi, M. (2003). Governance matters III. Governance indicators for 1996-2002. Washington: The World Bank. Available from internet: http://siteresources.worldbank.org/ INTWBIGOVANTCOR/Resources/govmatters3 wber.pdf. https://doi.org/10.1596/1813-9450-3106

Kaufmann, D., Kraay, A., \& Zoldo-Lobaton, P. (1999). Governance matters. Policy research. International Bank for Reconstruction and Development. The World Bank. Working Paper 2196, 1-64. https://doi.org/10.1596/1813-94502196

Kisman, Z. A., \& Tasar, I. (2014). The key element of local development. Procedia Economics and Finanse, 15/2014, 1689-1696. https://doi.org/10.1016/S2212-5671(14)00642-X

Knack, S., \& Keefer, P. (1995). Institutions and economic performance: cross-country tests using alternative institutional measures. Economics \& Politics, 7(3), 207-227. https://doi.org/10.1111/j.1468-0343.1995.tb00111.x

Knack, S., \& Keefer, P. (1997). Does social capital have an economic payoff? A cross-country investigation. The Quarterly Journal of Economics, 112(4), 1251-1288. https://doi.org/10.1162/003355300555475

Landes, D. S. (2000). Bogactwo i nędza narodow: dlaczego jedni są tak bogaci a inni tak ubodzy? Warszawa: Muza.

Law, S. H., \& Azman-Saini, W. N. W. (2012). Institutional quality, governance, and financial development. Economics of Governance, 13, 217-236. https://doi.org/10.1007/s10101-012-0112-z

Lizinska, W., Marks-Bielska, R., Babuchowska, K., et al. (2016). Institutional efficiency of local government in issuing administrative decisions, exemplified by the performance of the local government appeal board in Olsztyn. Oeconomia Copernicana, 7(2), 285-296. Availabla from internet: https://www.researchgate.net/publication/ 310737742_nstitutional_Efficiency_Of_Local_Government_In_Issuing_Administrative_Decisions_Exemplified_By The_Performance_Of_The_Local_Government_Appeal_Board_In_Olsztyn.

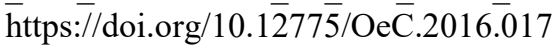

Lizinska, W., Marks-Bielska, R., Babuchowska, K., et al. (2017). Factors contributing to the institutional efficiency of local governments in the administrative area. Equilibrium: Quarterly Journal of Economics and Economic Policy, 12(2), 339-353. Available from internet: https://www.researchgate.net/publication/318665605_Factors_contributing_to_ the_institutional_efficiency_of_local_governments_in_the_administrative_area.https://doi.org/10.24136/eq. v12i 2.18

MacLeod, G., \& Goodwin, M. (1999). Reconstructing an urban and regional political economy: on the state, politics, scale, and explanation. Political Geography, 18(6), 697-730. https://doi.org/10.1016/S0962-6298(99)00014-1

Marks-Bielska, R., \& Kurowska, K. (2017). Institutional efficiency of communes in Poland in respect of space management. In: Conference proceedings of 17th international multidisciplinary scientific geoconference SGEM 2017. Ecology, economics, education and legislation. Albena, Bulgaria, 29 June-5 July, Issue 53, pp. 521-528.

Marks-Bielska, R., Lizinska, W., Babuchowska, K., et al. (2017). Factors determing the institutional efficiency of selfgovernment in the economic and spatial area. Barometr Regionalny, 15(1), 67-75. Available from internet: http://br.wszia.edu.pl/zeszyty/pdfs/br47_07marks.pdf.

Minniti, M., \& Levesque, M. (2008). Recent developments in the economics of entrepreneurship. Journal of Business Venturing, 23(6), 603-612. https://doi.org/10.1016/j.jbusvent.2008.01.001

Mauro, P. (1995). Corruption and growth. The Quarterly Journal of Economics, 110(3), 681-712. https://doi.org/10. $2307 / 2946696$ 
Milaszewicz, D. (2017). Jakosc rządu a dostęp do dobr publicznych w Polskich regionach. Prace Naukowe Uniwersytetu Ekonomicznego we Wroclawiu, (465), 114-122. Available from internet: http://www.dbc.wroc.pl/dlibra/docmetadata? id $=36933 \&$ from=publication. https://doi.org/10.15611/pn.2017.465.12

North, D. C. (1984). Three approaches to the study of institutions. In: D. C. Colander (Ed.) Neoclasical political economy. Cambridge: Ballinger, pp. 33-40.

Putnam, R. D. (1995). Demokracja w dzialaniu. Tradycje obywatelskie we wspolczesnych Wloszech. Warszawa: Spoleczny Instytut Wydawniczy, Znak.

Robbins, S. P., \& DeCenzo, D. A. (2002). Podstawy Zarządzania. Warszawa: PWE.

Rodrik, D. (1999). Where did all the growth go? External shocks, social conflict, and growth collapses. Journal of Economic Growth, 4(4), 385-412. https://doi.org/10.1023/A:1009863208706

Rodrik, D. (2003). In search of prosperity. analytic narratives on economic growth. Priceton and Oxford: Princeton University Press. https://doi.org/10.1515/9781400845897

Rodrik, D., Subramanian, A., \& Trebbi, F. (2004). Institutions rule: the primacy of institutions over geography and integration in economic development. Journal of Economic Growth, 9(2), 131-165. https://doi.org/10.1023/B:JOEG. 0000031425.72248 .85

Shane, S. (2009). Why encouraging more people to become entrepreneurs is bad public policy. Small Business Economics, 33(2), 141-149. https://doi.org/10.1007/s11187-009-9215-5

Stec, M., Filip, P., Grzebyk, M., \& Pierscieniak, A. (2014). Socio-Economic Development in the EU Member States Concept and Classification. Inzinerine Ekonomika-Engineering Economics, 25(5), 504-512. Available from internet: http://www.inzeko.ktu.lt/index.php/EE/article/viewFile/6413/4339. https://doi.org/10.5755/j01.ee.25.5.6413

Stoker, G. (2011). Was local governance such a good idea? A global comparative perspective. Public Administration, 89(1), 15-31. https://doi.org/10.1111/j.1467-9299.2011.01900.x

Swianiewicz P., \& Dziemianowicz W., \& Mackiewicz M. (2000). Sprawnosc instytucjonalna administracji samorządowej w Polsce. Gdansk: Instytut Badan nad Gospodarka Rynkowa.

Tomini, L. (2011). Improving quality of government. The EU's influence in central and Eastern European Countries during the enlargement process. Paper presented at the ECPR-IPSA Joint Conference, Whatever happened to north-south?, University of Sao Paulo, Brazil, Wednesday 16-Saturday 19 February 2011, pp. 7-10; www.paperroom.ipsa.org/ papers/paper_26208.pdf.

Torres, L., Pina, V., \& Yetano, A. N. A. (2011). Performance measurement in Spanish local governments. A cross-case comparison study. Public Administration, 89(3), 1081-1109. https://doi.org/10.1111/j.1467-9299.2011.01919.X

Walzer, N., (ed.) (2009). Entrepreneurship and local economic development. LEXINGTON BOOKS, United Kingdom.

Wilkin, J. (2013). Jakosc rzadzenia w Polsce. Jak ja badac, monitorowac i poprawiac? Warszawa: Wydawnictwo Naukowe Scholar.

Williams, D. (1997). Strategies of multinational enterprises and the development of the Central and Eastern European economies. European Business Review, 97(3), 134-138. https://doi.org/10.1108/09555349710167549

Williams, C. C., \& Shahid, M. S. (2016). Informal entrepreneurship and institutional theory: Explaining the varying degrees of (in)formalization of entrepreneurs in Pakistan. Entrepreneurship \& Regional Development, 28(1/2), 1-25. https://doi.org/10.1080/08985626.2014.963889

Williams, N., Vorley, T., \& Williams, C. C. (2017). Entrepreneurship and institutions. The causes and consequences of institutional asymmetry. London: Rowman \& Littlefield International.

Wojarska, M., Marks-Bielska, R., Lizinska, W., et al. (2017) Social service provision as determinant of institutional efficiency of local self-governments. Economics and Law, 16(1), 107-118. https://doi.org/10.12775/EiP.2017.008

Wojarska M., Marks-Bielska R., Lizinska W., et al. (2018). Institution efficiency versus the level of development of local governments (a study at the level of Poland's regional division). Acta Scientiarum Polonorum. Oeconomia, 17(2), 133-144. https://doi.org/10.22630/ASPE.2018.17.2.29

Woolcock, M., \& Narayan, D. (2000). Social capital: implications for development theory, research, and policy. The World Bank Research Observer, 15(2), 225-249. Available from internet: https://www.researchgate.net/publication/ 5217916_Social_Capital_Implications_for_Development_Theory_Research_and_Policy.https://doi.org/10.1093/wbro/ 15.2.225

The article has been reviewed.

Received in December 2018; accepted in June 2020. 